\title{
CORRIGENDUM
}

\section{Selective oncolytic effect of an attenuated Newcastle disease virus (NDV-HUJ) in lung tumors}

\section{B Yaacov, E Elihaoo, I lazar, M Ben-Shlomo, I Greenbaum, A Panet and Z Zakay-Rones}

Cancer Gene Therapy (2008) 15, 832; doi:10.1038/cgt.2008.56

Cancer Gene Therapy (2008) 15, 795-807;

doi:10.1038/cgt.2008.31

The authors have noticed a spelling error in the author line.
The correct author is shown below.

\section{E Eliahoo}

The authors would like to apologize for this mistake. 